\title{
Art as an instrument to understand the nature of suffering
}

We continue with our series of articles regarding Art as an educational tool in medicine. ${ }^{1}$ This time, we will describe the nature of human suffering, an inherent partner of patients, their families and health care providers in particular, and of the entire human race in general. In this article, we will explore the nature of suffering in light of Marcel Proust's thoughts, who was an authority on this subject because he embodied both a literary genius and a chronically-ill patient with severe asthma. ${ }^{2,3}$

So we will base our analysis on two of Proust's most recognized quotes about suffering, reflected in "The Sweet Cheat Gone"4 and "Sodom and Gomorrah" ${ }^{\prime \prime}$ from his masterpiece In Search of Lost Time. Let us take a look at the first quote: "We are healed of a suffering only by experiencing it to the full". ${ }^{4}$

Here Proust refers to the concept of pain being unavoidable because it depends on circumstances that are external to us (pain is inherent to existence itself); on the contrary, suffering is optional because it is actually a product of our mind. It is our mind that is potentially capable of banishing suffering through re-interpretation; that is what Proust means by "experiencing it to the full". Of course voluntarily seeking pain makes no sense -that would be masochism-, but once pain is here, it should be embraced. This does not mean yielding (resignation), it means experiencing pain with composure in order to achieve its resolution (redefinition). This is to say that, although we may go through painful situations, we are the masters of the approach that we will adopt to face them (Frankl). ${ }^{6}$

This refers to Nietzsche's amor fati (love of fate) or accepting the pain imposed on us to transform it and prevent it from turning into suffering (a useless mental reverberation of said pain) and, at the same time, cast it into actions aimed at overcoming it. ${ }^{7}$

Let us take a look at the second quote from Proust: "Illness is the doctor to whom we pay most heed; to kindness, to knowledge, we make promise only; pain we obey." ${ }^{5}$

With this concept, Proust conveys the idea that pain is a bitter gift of life since it implies a chance of spiritual growth. Pain shows us our vulnerability and therefore pushes us away from the comfort of our personal space (ego), a place we would have not left spontaneously, and it teaches us to appreciate the value of its absence (pain-pleasure dyad), it overrides our pride, promotes our approach to our fellow men (when pain is shared, it ameliorates) and shows us a path that, if followed, will lead us to development and transcendence. When pain, either physical or spiritual, does not result in suffering but in understanding, it turns into strength (Nietzsche). ${ }^{7}$

Pain may be the engine of personal development; it causes an inner shock (fracture) that is essential for an intellectual restructuring that will lead us to spiritual development. It is because pain makes us uncomfortable that it stimulates change and an ambitious transformation, but undertaking it is our task. Understanding the true meaning of pain (a real and momentary fact) and how it differs from suffering (perpetuation of a mental construct) is highly valuable for health care providers to acquire the ability to mentally grasp their personal suffering and be able to help sick patients comprehend their own suffering in a sort of "spiritual alchemy" that transforms lead (pain) into gold (mental development) (Jung). ${ }^{8}$

To sum up, understanding the nature and goal of suffering is essential for health care providers, both at a personal and an occupational level, and art is a valuable resource to achieve such understanding.

Carlos G. Musso, M.D., and Paula A. Enz, M.D. School of Medicine, Instituto Universitario del Hospital Italiano de Buenos Aires, Argentina

http:/ /dx.doi.org/10.5546/aap.2016.eng.196

\section{REFERENCES}

1. Musso CG, Enz PA. El arte como instrumento educativo en medicina. Arch Argent Pediatr 2014;112(6):494-5.

2. Beutler M. Los hombres de la historia. Proust. Buenos Aires: Centro Editor de América Latina; 1986.

3. Musso CG. Obras maestras del arte universal y la medicina: En busca del tiempo perdido de Marcel Proust (1871-1922). Evid Actual Pract Ambul 2012;15(2):58.

4. Proust M. En busca del tiempo perdido: Albertina ha desaparecido. Buenos Aires: CS Ediciones; 2006.

5. Proust M. En busca del tiempo perdido: Sodoma y Gomorra. Buenos Aires: CS Ediciones; 2006.

6. FranklVE. Elhombre en busca de sentido. Barcelona:Herder; 1991.

7. Valesi E. Friedrich Nietzsche. La máscara de Dionisos. Buenos Aires: Lea; 2012.

8. Jung CG. El libro rojo. Buenos Aires: El hilo de Ariadna; 2012. 


\section{Use and abuse of anti-angiogenic drugs for Retinopathy of Prematurity treatment in Argentina in 2015}

Please allow us to start this comment by copying the title of an article published in $2012^{1}$ by Graham Quinn (USA), Brian Darlow (NZ) and Andrea Zin (UK), international reference leaders in the field of retinopathy of prematurity (ROP) prevention, diagnosis and management.

Knowledge on the cascade of vasoproliferative factors involved in the development of the retinal vasculature raised the interest in the use of antiangiogenic drugs for severe ROP treatment. Bevacizumab has been publicized as one of the most effective drugs.

A randomized, multicenter study (14 hospitals from Texas, USA) conducted by Mintz-Hittner et al., ${ }^{2}$ called BEAT-ROP, and published by the New Engl J Med in 2011 in spite of the small population enrolled (143 infants treated, 286 eyes), concluded boosting the use of Avastin ${ }^{\circledR}$ (bevacizumab) as the treatment of choice for zone I severe ROP or aggressive posterior ROP (AP-ROP), ${ }^{3}$ also known as "rush" disease due to its rapid progress to retinal detachment.

The actual effectiveness of this off-label use (not validated by the manufacturer) led to a rapidly growing use of bevacizumab without consideration of its potential side effects. The BEAT-ROP study was not designed to assess the ocular and general side effects of bevacizumab. It also omitted to study the serum drug concentration and the time it remains in the bloodstream or its excretion (it has been detected up to 15 days following intraocular administration).

It is worth noting that ROP develops at a gestational age when lung, kidney and brain vessels, among others, grow rapidly. The interruption of such growth by the direct action of anti-angiogenic drugs may result in severe, still unknown, sequelae in the long term.

However, for those of us who have experienced ROP from the times of retrolental fibroplasia (RLF) as nothing but witnesses of terminal blindness, followed by the first classification in 1984, which allowed us to settle in "time and space", up to the subsequent cryotherapy and laser treatment for retinal ablation and their varying outcomes and side effects, the physiopathological interpretation presented in March 2001 by the Swedish group led by Ann Hellstrom ${ }^{4}$ in Proceedings of the
National Academy of Sciences of USA (PNAS) and endorsed by Mary Ellen Avery was a milestone, a turning point that allowed us to become aware of the action of insulin-like growth factor 1 (IGF1) and vascular endothelial growth factor (VEGF) in the normal development of the retina and ROPinduced changes.

Since that time, therapeutic research focused on intravitreal VEGF blocking using antiangiogenic drugs, which were then booming for the treatment of cancer and multiple organ metastases. The different drug studies gradually focused on bevacizumab, specifically Avastin ${ }^{\circledR}$, as the drug of choice.

The excitement observed among ophthalmologists with experience in the treatment of ROP was understandable, and was supported by the lower level of retinal damage and the lower number of treatment repetitions needed, compared to cryotherapy and laser treatment.

However, its off-label use restricted its indication. Finally, the Drug, Food and Technology Administration of Argentina (ANMAT) approved its use in well-defined circumstances: stage 3+ plus disease or aggressive posterior ROP, in accordance with a hospital protocol, and with the parents' informed consent. Similar indications had been proposed by MintzHittner ${ }^{5}$ in 2009.

Its indication in the case of laser treatment failure was also widely disseminated among pediatric ophthalmologists as a humanitarian measure against an imminent severe visual disability.

The ROP Argentina Group has recommended the following in its recently published Clinical Practice Guidelines (CPGs) for ROP prevention, diagnosis and management ${ }^{6}$ : "Consider intravitreal bevacizumab monotherapy (with no need for laser photocoagulation) before retinal detachment in zone I ROP stage 3 plus disease (not in zone II), with bleeding, rigid pupil, intravitreal neovascularization (with minimal fibrosis) or aggressive posterior ROP (AP-ROP): $0.625 \mathrm{mg}$ pars plana intravitreal injection at $2 \mathrm{~mm}$ from the limbus".

However, severe ROP stages, directly related to gestational age, are uncommon although their prevalence is higher among the more immature patients. Considering all treated infants, AP-ROP 
accounts for $5 \%$ to $10 \%$ of cases; i.e., 1 in every 10-20 preterm infants may have an indication for intraocular anti-angiogenic drugs.

To date, its use is mostly indicated in the case of severe disease that may rapidly result in retinal detachment and blindness.

But at the beginning of this article, we mentioned an abuse (Merriam-Webster: improper or excessive use or treatment) of anti-angiogenic drugs for ROP treatment in Argentina in 2015.

Figure 1 shows the data provided by the ROP Argentina Group (at the $14^{\text {th }}$ National Conference, $37^{\text {th }}$ Argentine Pediatrics Congress organized by the SAP in Mendoza, 2015) from 88 Departments of Neonatology across the 24 Argentine provinces, with a total of 212834 births reported in 2014. Among 7371 infants at risk of ROP $(2502<1500 \mathrm{~g})$, 1000 developed the disease and one fourth required treatment (265).

After a "controlled" initial syndicated use in 2011 and 2012, bevacizumab use increased surprisingly. In $2014,18 \%$ of patients received anti-angiogenic drugs as monotherapy or combined with laser treatment, i.e., almost 1 in every 5 treated children.

This information is even more concerning once we analyze data from 2015 (first semester): 29\% of cases received bevacizumab, i.e., 1 in every 3 children!

This is not a new reality. In the field of medicine there are many examples of an excessive drug indication resulting from initial, practically "magical" results with no evidence supporting their use and potential side effects.

FIgure 1. Percentage of all newborn infants treated with bevacizumab (Avastin) out of all treated infants, as monotherapy or combined with laser treatment, between 2011 and 2014. Source: ROP Argentina Group (authorized)
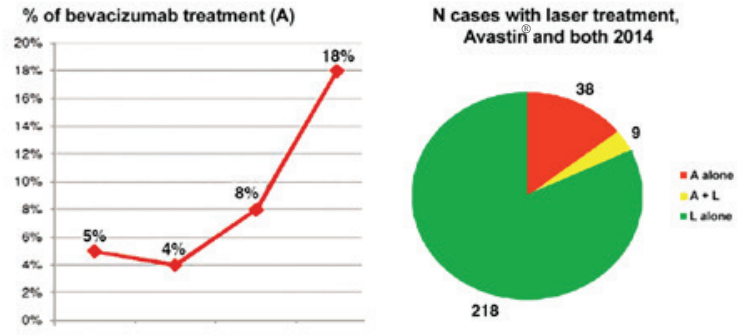

Research on anti-angiogenic drugs for ROP has not focused exclusively on bevacizumab; there is also experience on the use of ranibizumab and propranolol. ${ }^{7}$ The greatest advantage of the latter is its oral administration and, in the near future, it may be administered in eye drops, a true therapeutic challenge.

There is no doubt that anti-angiogenic drugs are part of ROP treatment; however, in any case, laser photocoagulation is still the "gold standard".

Rigorous multicenter, controlled clinical trials with long-term follow-up are required to provide evidence that will warrant the correct indication of these drugs for a disease that may cause a lifelong disability. ${ }^{8}$ Given the current state of knowledge on this promising therapy, caution should be our priority.

Ernesto Raúl Alda

Head of the Department of Neonatology, Hospital Privado del Sur, Bahía Blanca.

Teacher at the Department of Health Sciences, Universidad Nacional del Sur. Bahía Blanca. Member of the ROP Argentina Group

http:/ /dx.doi.org/10.5546/aap.2016.eng.197

\section{REFERENCES}

1. Quinn GE, Darlow BA, Zin AA. Use and abuse of antiangiogenic drugs for ROP treatment. Vision 2020 Latinoamérica Boletín trimestral. January 2012. Available at: https://vision2020la. wordpress.com/traducciones/useand-abuse-of-anti-angiogenic- drugs-for-rop-treatment/

2. Mintz-Hittner HA, Kennedy KA, Chuang AZ. Efficacy of intravitreal bevacizumab for stage 3+ retinopathy of prematurity. N Engl J Med 2011;364(7):603-15.

3. Reynolds JD. Bevacizumab for retinopathy of prematurity. N EnglJ Med 2011;364(7):677-8.

4. Hellstrom A, Perruzzi C, Ju M, Engstrom E, et al. Low IGF-I suppresses VEGF-survival signaling in retinal endothelial cells: direct correlation with clinical retinopathy of prematurity. ProcNatlAcadSci USA 2001;98(10):5804-8.

5. Mintz-Hittner HA, Best LM. Antivascular endothelial growth factor for retinopathy of prematurity. CurrOpinPediatr 2009;21(2):182-7.

6. Grupo ROP Argentina. Ministerio de Salud. Guía de Práctica Clínica para la prevención, diagnóstico y tratamiento dela Retinopatía del Prematuro(ROP). Buenos Aires, 2015. [Accessed on: January 12,2016]. Available at: http:/ / www. msal.gob.ar/images/stories/bes/graficos/0000000723cntguia-pract-clin-ROP-2015.pdf.

7. Filippi L, Cavallaro G, Bagnoli P, Dal Monte M, et al. Oral propranolol for retinopathy of prematurity: risks, safety concerns, and perspectives. J Pediatr 2013;163(6):1570-7.

8. Pertl L, Steinwender G, Mayer C, Hausberger S, et al. A systematic review and meta-analysis on the safety of Vascular Endothelial Growth Factor (VEGF) Inhibitors for the treatment of retinopathy of prematurity. PLoS One 2015;10(6):e0129383. 